Review

\title{
Genetic Explanations for Fertility Disorders
}

Joep Geraedts *

Department Genetics and Cell Biology, Maastricht University Medical Center, P.O. Box 5800, 6200 AZ MAASTRICHT, Netherlands; E-Mail: joep.geraedts@mumc.nl

* Correspondence: Joep Geraedts; E-Mail: joep.geraedts@mumc.nl

Academic Editor: Helena Kääriäinen

Special Issue: Genetic Testing

OBM Genetics

2020, volume 4, issue 2

doi:10.21926/obm.genet.2002111
Received: May 02, 2020

Accepted: June 15, 2020

Published: June 23, 2020

\begin{abstract}
This article reviews the genetic testing of infertility disorders. Genetic abnormalities can lead to disturbances of sexual development and hamper reproduction by influencing gamete production and maturation, fertilization, and embryonic development. Until now, the vast majority of detectable genetic abnormalities causing infertility were chromosomal abnormalities in both males and females. However, the number of monogenetic disorders, which play a role in disturbing fertility, such as single gene defects or complex disorders involving multiple genes in combination with environmental factors, is increasing. The common genetic causes of infertility in males are sex chromosomal abnormalities, Robertsonian translocations, cystic fibrosis transmembrane conductance regulator (CFTR) mutations, and $Y$ chromosome microdeletions. In females, Turner syndrome, genetic causes of premature ovarian failure, such as $\mathrm{fra}(\mathrm{X})$ and complex disorders like polycystic ovary syndrome (PCOS), and endometriosis are the most prevailing. However, insight into the total impact of genetic abnormalities is increasing. This is because a growing number of mutations are detected among subfertile patients with an unknown etiology.

Genetics is one of the most important yet under-emphasized causes of subfertility. Improved understanding of the genetics of infertility holds promise to define the etiology and counsel cases that were previously diagnosed with idiopathic infertility.
\end{abstract}

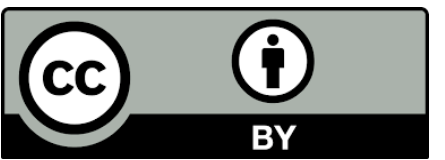

(C) 2020 by the author. This is an open access article distributed under the conditions of the Creative Commons by Attribution License, which permits unrestricted use, distribution, and reproduction in any medium or format, provided the original work is correctly cited. 


\section{Keywords}

Female infertility; male infertility; genetic abnormalities; chromosome abnormalities; Ychromosome deletions; gene mutations; genetic fertility screening

\section{Introduction}

Genetic abnormalities can disturb several reproductive processes. In order to function these processes normally, sex determination and sexual development, hormonal actions and interactions, gametogenesis, fertilization, implantation, and early embryo development, should occur precisely to lead to the birth of living and healthy offspring. Hundreds of genes have to work together normally to achieve this.

Infertility is a disease defined by the failure to achieve a successful pregnancy after 12 months or more of regular, unprotected sexual intercourse or due to an impairment to reproduce either as an individual or with her/his partner [1]. Approximately 1 out of 6 people suffer from it during their reproductive lifespans [2]. Both male and female factors contribute to infertility. In about $20 \%$ of cases, the male factors contribute to the main etiology, and in further $30 \%$ to $40 \%$ they are in combination with female factors [3]. The relationship between recognizable genetic abnormalities and fertility disorders has become decisive and clearer during the last decades. There are several ways in which the genetic constitution reflects itself during reproduction in both genders.

Primarily, hereditary abnormalities might result in congenital abnormalities of the reproductive organs and disturbed function of the genitals. To remain healthy and function productively, sufficient healthy oocytes and spermatozoa must be produced to give the processes of fertilization and embryonic development, a reasonable probability of success. Both the male and female gametes carry a random combination of $50 \%$ of the genetic content of the future parent. If everything proceeds normally, one allele of each gene of the individual will be transmitted to the next generation. Subfertility or infertility might result from the insufficient production or total absence of gametes. Gametes with functional defects may prevent fertilization. Furthermore, the defect may disturb early embryonic development, or embryonic lethality may manifest itself after implantation.

In most cases, patients with fertility problems present themselves only after puberty. However, during neonatal life, diagnostic questions might emerge because of ambiguous genitalia.

\section{Genetic Testing}

Genetic testing of fertility disorders begins with chromosome analysis. Soon after the discovery of the chromosomal abnormalities in Turner and Klinefelter syndromes [4, 5], the cytogenetic analysis was introduced for diagnostic purposes. This was extended after the role of structural chromosome abnormalities, including translocations, became clear [6].

In the eighties of the last century, molecular techniques for the diagnosis of single-gene disorders have been introduced.

Since the completion of the human genome project and impressive improvements in the 
development of new genetic technologies, it is possible to study the entire genome (or its coding part) for disease-causing mutations [7]. This can be achieved free of clinical bias. Whole-genome sequencing (WGS) and whole-exome screening (WES) are used to detect already known gene mutations, as well as to detect new genes. With the discovery of newer genes and mutations, the toolbox to test patients suffering from subfertility is broadened.

Two types of genetic testing can be distinguished:

1. Genetic diagnosis: to detect if a person or a couple, who is infertile, has an associated genetic disorder.

2. Genetic screening: to detect if a person or a couple is at increased risk of being infertile.

The genetic methods used for both types of testing are identical. However, the evaluation should be conducted in a cost-effective manner, as some methods might be too expensive to be applied for screening. Multigene panels test several relevant markers in a single test but might be a compromise between the low cost-effectiveness of single-gene tests and the application of NGS [8]. However, the finding of gene variants of questionable clinical effect is incomprehensible [9]. Genetic fertility screening is now commercially available for both preconception [10] as well as family carrier screening [11].

\section{Abnormal Sexual Development}

Disorders (or Differences) of Sex Development (DSD) comprise a spectrum of variations of sexual development.

DSD can be classified as follows [12]:

1. Sex chromosomal DSD

Besides (variants of) the Klinefelter and Turner syndromes, the $45, X / 46, X Y$ mosaicism and the 46, $X X / 46, X Y$ chimerism belong to this group.

\section{2. $46, X Y D S D$}

This group of under-virilization syndromes is characterized by androgen deficiency. Besides disorders of testicular development, there are abnormalities in androgen synthesis or action. Androgen synthesis is a stepwise process starting from cholesterol. There is a deficiency of each of the enzymes catalyzing the different metabolic reactions. Androgen insensitivity syndromes result from mutations in the androgen receptor. More than 1000 mutations of the androgen receptor (AR) gene, which is located on Xq11-12 have been described [13].

The persistent Müllerian duct syndrome (PMDS) is a rare disorder characterized by the persistence of Müllerian derivatives in an otherwise normally virilized 46, XY male. It is usually caused by mutations in either the anti-Müllerian hormone (AMH) or $A M H$ receptor type 2 (AMHR2) genes [14].

\section{3. $46, X X D S D$}

This group of over-virilization syndromes belongs to the disturbances of ovary development, with the abnormalities arising from an excess of androgens, and other defects. The reason for an excess of androgen can be fetal (for example, as a result of congenital adrenal hyperplasia), fetoplacental (due to aromatase deficiency), or maternal (by the presence of a tumor or exogenous androgens).

Over the years, several genes involved in the development and differentiation of the embryonic gonads have been identified whose disruption can lead to disorders of sex development. A genetic 
diagnosis was made in 8 out of 21 patients with DSD when tested with a panel of 219 genes [15]. When a targeted DSD gene panel was used to sequence 64 DSD genes in a cohort of more than 326 patients with DSD, a genetic diagnosis was identified in $43 \%$ cases [16]. Also, a more recent study has confirmed that the use of an NGS panel approach is a clinically useful and cost-effective diagnostic tool [17]. However, improvement is needed since more than half of the DSD patients cannot yet be genetically diagnosed [18].

\section{Congenital Hypogonadotropic Hypogonadism (CHH)}

The identification of genes mutated in patients with $\mathrm{CHH}$ has increased considerably during the last ten years [19]. The complete or partial failure of pubertal development, which is seen in $\mathrm{CHH}$ results from deficient production, secretion, or action of gonadotropin-releasing hormone (GnRH), leading to gonadotropin deficiency [20].

$\mathrm{CHH}$ includes two groups of patients. The first has Kallmann syndrome (KS), which is characterized by gonadotropin deficiency with a defective sense of smell (i.e., anosmia or hyposmia). The second does not show olfactory defects. The anosmin-1 gene also known as the Kallmann syndrome 1 (KAL1) gene, is one of the most commonly involved genes in $\mathrm{CHH}$ and is responsible for the X-linked recessive form of KS located on chromosome Xp22.31 [21].

Recently, a large cohort of 130 unrelated patients (91 males, 39 females) with CHH was tested genetically using a panel that contained $36 \mathrm{CHH}$-associated genes. Potential or probable pathogenic variants were identified in $43(33 \%)$ patients. The most frequently affected genes were ANOS1, FGFR1, and GNRHR. Notably, $6.9 \%$ of the patients had rare variants in more than one gene [22].

\section{Abnormal Ovarian Development and Function}

Pregnancies of all embryos having a karyotype with one intact $X$ chromosome, i.e., $45, X$ or Turner syndrome (TS) end almost invariably as miscarriage [23]. Therefore, most of the living TS patients are mosaics [24]. At birth, most children go unrecognized. The hallmarks of the syndrome are short stature and premature ovarian insufficiency (POF) [25]. The 47, XXX karyotype has a frequency of about 1 in 1000 female newborns. However, this karyotype is seldom suspected at birth or childhood. These patients show a variable phenotype, and some are diagnosed when they develop POF or infertility during adulthood [26]. The diagnosis of POF is based on the occurrence of amenorrhea before the age of 40 , associated with follicle-stimulating hormone levels in the menopausal range [27]. Up to $40 \%$ of POF can be attributed to genetic causes [28]. Besides chromosomal abnormalities, several genes are involved [27]. These include mutations of genes involved in granulosa cell differentiation, follicle growth, and oocyte development and maturation [29]. Furthermore, both somatic genes and germ cell genes play a role during morphogenesis of follicles from primordial germ cells to secondary follicles [30]. FMR1 gene premutation is the most frequently found abnormality in women with idiopathic sporadic POF [31]. Premutation means that the FMR1 gene shows expansion between 55 and 199 CGG repeats. Above this, the most frequent type of hereditary mental retardation, the complete fragile X-syndrome, occurs [32].

Despite galactose-restricted dietary treatment, primary ovarian insufficiency was present in about $80 \%$ of female galactosemia patients [33]. 


\section{Oocyte Maturation Failure}

By the introduction of IVF, oocyte maturation failure has become a known, although rare cause of female infertility. After the first patient was described in 1990, several cases have been reported in the following years, but the molecular causes for the symptoms in these patients remained unknown [34]. Recently TUBB8 mutations have been found to cause oocyte arrest at the MI stage [35]. TUBB8 is a highly conserved primate-specific $\beta$-tubulin isotype that is specifically expressed in oocytes and early embryos. The inherited or de novo mutants of the TUBB8 gene accounted for about $30 \%$ of individuals in a small cohort of patients affected by oocyte maturation [36]. PATL2 is the other gene that is frequently involved. Using whole-exome sequencing, it was found that one in four patients had the same homozygous nonsense pathogenic PATL2 mutation [37].

\section{Abnormal Spermatogenesis: Azoospermia and Oligozoospermia}

Males with disturbed fertility might have one or more $\mathrm{X}$-chromosomes as well as a $\mathrm{Y}$ chromosomes. The Klinefelter syndrome, with the karyotype $47, \mathrm{XXY}$ is present in about 1 of every 1000 new-born boys [38]. Mostly the diagnosis is made only after puberty based on the undeveloped secondary sexual characteristics and small testicles. About $10 \%$ of males, referred to an infertility clinic because of non-obstructive azoospermia, are diagnosed to have Klinefelter syndrome. Therefore, this syndrome is the most prevalent chromosomal abnormality and the genetic cause of azoospermia in males [39]. Also, the 47, XYY syndrome is present in about 1 in 1000 new-born males [40]. Usually, the sexual development of these boys' proceeds without any fertility problems. The percentage of sex chromosome abnormalities is strongly dependent on the number of sperms with which the patient presents himself. The Klinefelter syndrome can be found in $14 \%$ of non-obstructive azoospermia patients, whereas structural autosomal anomalies (translocations/inversions) are more frequent in oligozoospermic men [19].

The number of spermatozoa is correlated with the percentage of chromosomal abnormalities. With less than 5 million spermatozoa/mL about $8 \%$ of the patients are abnormal and between 5-10 million, about $5 \%$. The group showing $10-20$ million spermatozoa/mL does not show a significant increase in comparison to the population level which is about $0.6 \%$. This suggests that there is no rationale to perform karyotype analysis in every single male entering assisted reproduction programs [41].

The microdeletions or AZF deletions on the long arm of the $Y$ chromosome represent the most important molecular genetic cause of oligo- and azoospermia [42].

There are five different deletion patterns, which have been designated as AZFa, AZFb, AZFb+c, and AZFc deletions [43]. In about $5-10 \%$ of NOA patients and 2-5\% of severe oligozoospermic patients, one or more of the AZF regions are removed $[44,45]$.

The phenotype depends on the deletion type, as the deletion of the entire AZFa leads to the Sertoli cell-only syndrome (SCOS). This syndrome is found in patients with complete AZFb and AZFbc deletions. However, they might also have spermatogenetic arrest (SGA). Sperm production can be found in patients with partial AZFa, partial AZFb, and complete AZFc deletions. The latter phenotype ranges from oligozoospermia to azoospermia [43].

Some X-chromosome deletions like CNV67 was found with a frequency of $1.1 \%$ in oligo/azoospermic men [46] and cause oligo/azoospermia. Most probably this is due to the 
deletion of the MAGEA9 gene [47], which shows exclusive physiological expression in the testis [48].

Deletions, as well as gains, such as DUP1A, can cause sperm abnormalities, which can be observed in more than $1 \%$ of patients. After the introduction of NGS, more than ten different autosomal recessive variants have been detected. However, these are all rare and almost exclusively found in consanguinity cases [19].

Male cystic fibrosis is the best-known monogenetic defect caused due to azoospermia by a congenital absence of the vas deferens (CAVD). More than 2000 different mutations of the cystic fibrosis transmembrane conductance regulator (CFTR) gene are known [49], and geographical and ethnic differences exist. The common mutations of the CFTR gene in CAVD patients are F508del, $5 \mathrm{~T}$, and R117H [50, 51].

In many fertility labs around the world, 20 most frequently occurring mutations of the CFTR gene are screened routinely. The phenotype of many mutations is heterogeneous and often less severe as the classical cystic fibrosis phenotype, which results from homozygosity of the delta $\mathrm{F}$ 508 mutation. Some mutations are specifically associated with male infertility.

If the CFTR gene shows no abnormalities, ADGRG2 testing is useful. In approximately $2 \%$ of the cases of CAVD, a mutation in the ADGRG2 gene can be found, which may cause a familial form of X-linked infertility [52].

Another recent and novel approach in the diagnostic detection of genes in idiopathic nonobstructive azoospermia (NOA) patients is the application of a gene panel based on genes associated with mouse azoospermia. This is relatively successful and has allowed the discovery of two novel genes involved in NOA due to meiotic arrest [53].

\section{Other Disorders}

Around 3435 human candidate genes have been defined to be potentially relevant to infertility or prenatal death [54]. However, the number of gene mutations already proven to be involved in infertility is relatively small. TEX11 has become well known, and many mutations have been found in azoospermic and infertile men [55]. In the testes, a gene located on the X chromosome (Xq13.1) encodes a protein necessary for male germ cell meiotic DNA recombination and chromosomal synapsis [56]. About half of all genes known to cause isolated testicular forms of infertility are involved in terato-zoospermia [57]. Specific gene mutations cause specific abnormalities [58] such as DPY19L2 and SPATA16, account for up to 70\% of all cases of globozoospermia [59] and AURKC mutations cause macrozoospermia [60]. Furthermore, there are 18 known genes whose mutations induce multiple morphological abnormalities of the flagella and infertility [61].

Also, sperm mitochondrial DNA copy numbers and deletions have been associated with poor semen parameters and clinical male infertility [62].

\section{Multifactorial Disorders}

Polycystic ovary syndrome (PCOS) is the most prevalent endocrine and metabolic disorder among women of reproductive age. It accounts for more than $75 \%$ of anovulatory infertility and affects 7 to $12 \%$ of women in their reproductive years [63]. Familial clustering has long been observed. However, the model of inheritance of PCOS has not yet been defined. Although some researchers have postulated autosomal dominant transmission linked to a single genetic defect, 
most authors define PCOS as a polygenic pathology.

Epigenetics also seems to play a role since a few metabolic components of the PCOS phenotype are programmed in utero. In a recent review, it has been suggested that a large number of genes, involved in different pathways, play a role in PCOS:

1. Genes involved in ovarian and adrenal steroid genesis (CYP11a; $17 ; 19$ and 21);

2. Genes involved in steroid hormone effects (AR and SHBG);

3. Genes involved in gonadotropin action and regulation ( $\mathrm{LH} ; \mathrm{AMH}$ and FSHR);

4. Genes involved in insulin action and secretion (INS; IRS-1; IRS-2 and CAPN10);

5. Genes involved in the epigenetics of PCOS (NCOR1 and PPARG1);

6. Other genes (FTO; PCOS1; SRD5A1 and SRD5A2) [64].

Endometriosis is another multifactorial disease where both the genetic constitution, as well as environmental factors, play a role. Besides the growth and proliferation of endometrial glands and stroma in ectopic sites, impaired fertility is one of the primary symptoms [65]. It shows familial clustering, which is well-established. However, the complex pattern of inheritance associated with it has not been elucidated yet. Several chromosomal loci are associated with endometriosis [66]. Furthermore, many genes are abnormally methylated in ectopic endometrial tissue [67].

\section{Failure of Fertilization and Zygote Cleavage}

The genetic basis of fertilization abnormalities in humans remains largely unknown. Recently homozygous mutations in WEE2 are shown to be responsible for fertilization failure in humans [68]. Mutations of TUBB8, as well as TLE6 and PADI6, are associated with complete cleavage failure [69-71]. Furthermore, mutations of TUBB8 can cause embryo fragmentation and early embryonic arrest [72, 73].

\section{Recurrent Implantation Failure}

Recurrent implantation failure might be due to both the seed and the soil, i.e., the embryo or the endometrium. Mutations in TUBB8 include oocyte maturation arrest, fertilization failure, early embryonic arrest, and a failure of embryo implantation [36]. Also, mutations in PADI6 cause female infertility characterized by early embryonic arrest [74]. Furthermore, FOXD1 is a major molecule involved in embryo implantation by regulating endometrial/placental genes. Therefore, FOXD1 mutations might also be involved in implantation disorders [75].

\section{Recurrent Pregnancy Loss}

Although recurrent pregnancy loss is a disease distinct from infertility, defined by two or more failed pregnancies $[1,76]$, it results in declined fertility and affects about $1 \%$ of the reproductive age population [77]. Parental chromosomal anomalies, maternal thrombophilic disorders, and structural uterine anomalies have been directly associated with recurrent miscarriage [78]. However, the pathophysiology remains unknown in the majority of cases [79]. Sporadic and recurrent miscarriage did not show significantly different chromosomal anomaly rates. Maternal age was the only statistically significant predictor of the chromosomal anomaly identified [80].

The ESHRE guideline states that although the genetic analysis of pregnancy tissue is not routinely recommended, it could be performed for explanatory purposes [81-84]. 
For genetic analysis of the pregnancy tissue, array-based comparative genomic hybridization (array-CGH) is recommended based on a reduced maternal contamination effect [85]. Parental karyotyping is not routinely recommended in couples with RPL. However, it could be carried out after an individual assessment of risk [86-90].

Recently, it has been shown that genomics approach to decipher single-gene causes in infertile women in whom endocrinological, anatomical, and chromosomal causes have been excluded, might offer new potential for the future [91]. This could be achieved by a trio (mother, father, and fetal tissue) based approach of exome sequencing in cases with normal parental karyotypes [78].

\section{Conclusions}

Many genes are involved in sex determination, reproductive organ development, gametogenesis, fertilization, implantation, and early embryo development. Each of these genes can mutate and cause infertility on its own or in interaction with other genes. Genetic testing of fertility disorders has started with a classical analysis of numerical and structural chromosomal abnormalities. The diagnostic yield after testing for male infertility was improved by microscopically visible and molecularly detectable $Y$ chromosome-deletions. In the female, the same sequence was followed by testing for the presence of a fragile $X$ chromosome.

Thereafter, molecular techniques for the diagnosis of single-gene disorders have been introduced. In the future, large scale-sequencing will likely bring about more monogenetic causes of infertility and the genes involved in disorders showing more complex patterns of inheritance. Furthermore, the role of the environment in the latter will become comprehensible by studying epigenetic defects.

\section{Author Contributions}

Joep Geraedts did all work.

\section{Competing Interests}

The author has declared that no competing interests exist.

\section{References}

1. Practice Committee of the American Society for Reproductive Medicine. Definitions of infertility and recurrent pregnancy loss: A committee opinion. Fertil Steril. 2020

2. Cariati F, D'Argenio V, Tomaiuolo R. The evolving role of genetic tests in reproductive medicine. J Transl Med. 2019; 17: 267.

3. Rumbold AR, Sevoyan A, Oswald TK, Fernandez RC, Davies MJ, Moore VM. Impact of male factor infertility on offspring health and development. Fertil Steril. 2019; 111: 1047-1053.

4. Ford CE, Jones KW, Polani PE, De Almeida JC, Briggs JH. A sex-chromosome anomaly in a case of gonadal dysgenesis (Turner's syndrome). Lancet. 1959; 1: 711-713.

5. Jacobs PA, Strong JA. A case of human intersexuality having a possible XXY sex-determining mechanism. Nature. 1959; 183: 302-303.

6. Gardner RJMK, Sutherland GR, Shaffer LG. Chromosome abnormalities and genetic counselling. 2nd ed. Oxford: Oxford University Press; 2011. 
7. Yohe S, Thyagarajan B. Review of clinical next-generation sequencing. Arch Pathol Lab Med. 2017; 141: 1544-1557.

8. Beim PY, Parfitt DE, Tan L, Sugarman EA, Hu-Seliger T, Clementi C, et al. At the dawn of personalized reproductive medicine: Opportunities and challenges with incorporating multigene panel testing into fertility care. J Assist Reprod Genet. 2017; 34: 1573-1576.

9. Collins SC. Precision reproductive medicine: Multigene panel testing for infertility risk assessment. J Assist Reprod Genet. 2017; 34: 967-973.

10. Prepregnancy Genetic Screening. Atlanta: Shady Grove Fertility; 2020. Available form: www.shadygrovefertility.com/diagnosing-infertility/fertility-tests/genetic-screening

11. Home - Thermo Fisher Scientific. Waltham: Thermo Fisher Scientific; 2020. Available form: www.thermofisher.com

12. Hughes IA, Houk C, Ahmed SF, Lee PA, LWPES Consensus Group, ESPE Consensus Group. Consensus statement on management of intersex disorders. Arch Dis Child. 2006; 91: 554563.

13. Gottlieb B, Beitel LK, Nadarajah A, Paliouras M, Trifiro M. The androgen receptor gene mutations database: 2012 update. Hum Mutat. 2012; 33: 887-894.

14. Tosca L, Giltay JC, Bouvattier C, Klijn AJ, Bouligand J, Lambert AS, et al. Persistent Müllerian duct syndrome due to anti-Müllerian hormone receptor 2 microdeletions: A diagnostic challenge. Hum Reprod. 2020 Mar 18.

15. Dong $\mathrm{Y}, \mathrm{Yi}$ Y, Yao H, Yang Z, Hu H, Liu J, et al. Targeted next-generation sequencing identification of mutations in patients with disorders of sex development. BMC Med Genet. 2016; 17: 23.

16. Eggers S, Sadedin S, van den Bergen JA, Robevska G, Ohnesorg T, Hewitt J, et al. Disorders of sex development: Insights from targeted gene sequencing of a large international patient cohort. Genome Biol. 2016; 17: 243.

17. Hughes LA, McKay-Bounford K, Webb E, Dasani $P$, Clokie S, Chandran H, et al. Next generation sequencing (NGS) to improve the diagnosis and management of patients with disorders of sex development (DSD). Endocr Connect. 2019; 8: 100-110.

18. Eid W, Biason-Lauber A. Why boys will be boys and girls will be girls: Human sex development and its defects. Birth Defects Res C Embryo Today. 2016; 108: 365-379.

19. Krausz C, Cioppi F, Riera-Escamilla A. Testing for genetic contributions to infertility: Potential clinical impact. Expert Rev Mol Diagn. 2018; 18: 331-346.

20. Boehm U, Bouloux PM, Dattani MT, de Roux N, Dode C, Dunkel L, et al. Expert consensus document: European consensus statement on congenital hypogonadotropic hypogonadism-pathogenesis, diagnosis and treatment. Nat Rev Endocrinol. 2015; 11: 547-564.

21. Hu Y, Bouloux PM. X-linked GnRH deficiency: Role of KAL-1 mutations in GnRH deficiency. Mol Cell Endocrinol. 2011; 346: 13-20.

22. Amato LGL, Montenegro LR, Lerario AM, Jorge AAL, Guerra Junior G, Schnoll $C$, et al. New genetic findings in a large cohort of congenital hypogonadotropic hypogonadism. Eur J Endocrinol. 2019; 181: 103-119.

23. Hook EB, Warburton D. Turner syndrome revisited: Review of new data supports the hypothesis that all viable $45, \mathrm{X}$ cases are cryptic mosaics with a rescue cell line, implying an origin by mitotic loss. Hum Genet. 2014; 133: 417-424. 
24. Zhong Q, Layman LC. Genetic considerations in the patient with Turner syndrome-45, X with or without mosaicism. Fertil Steril. 2012; 98: 775-779.

25. Dabrowski E, Jensen R, Johnson EK, Habiby R, Brickman WJ, Finlayson C. Turner syndrome systematic review: Spontaneous thelarche and menarche stratified by karyotype. Horm Res Paediatr. 2019; 92: 143-149.

26. Goldschmidt E, Márquez M, Solari A, Ziembar MI, Laudicina A. Phenotypic variability in 47, XXX patients: Clinical report of four new cases. Arch Argent Pediatr. 2010; 108: e88-91

27. Cordts EB, Christofolini DM, Dos Santos AA, Bianco B, Barbosa CP. Genetic aspects of premature ovarian failure: A literature review. Arch Gynecol Obstet. 2011; 283: 635-643.

28. Meczekalski B, Podfigurna-Stopa A. Genetics of premature ovarian failure. Minerva Endocrinol. 2010; 35: 195-209.

29. Chapman C, Cree L, Shelling AN. The genetics of premature ovarian failure: Current perspectives. Int J Womens Health. 2015; 7: 799-810.

30. Pelosi E, Forabosco A, Schlessinger D. Genetics of the ovarian reserve. Front Genet. 2015; 6: 308.

31. Sherman SL, Taylor K, Allen EG. FMR1 premutation: A leading cause of inherited ovarian dysfunction. Fragile sites: New discoveries and changing perspectives. New York: Nova Science Publishers; 2007.

32. Allen EG, Sullivan AK, Marcus M, Small C, Dominguez C, Epstein MP, et al. Examination of reproductive aging milestones among women who carry the FMR1 premutation. Hum Reprod. 2007; 22: 2142-2152.

33. Rubio-Gozalbo ME, Haskovic M, Bosch AM, Burnyte B, Coelho Al, Cassiman D, et al. The natural history of classic galactosemia: Lessons from the GalNet registry. Orphanet J Rare Dis. 2019; 14: 86.

34. Rudak E, Dor J, Kimchi M, Goldman B, Levran D, Mashiach S. Anomalies of human oocytes from infertile women undergoing treatment by in vitro fertilization. Fertil Steril. 1990; 54: 292-296.

35. Feng R, Yan Z, Li B, Yu M, Sang Q, Tian G, et al. Mutations in TUBB8 cause a multiplicity of phenotypes in human oocytes and early embryos. J Med Genet. 2016; 53: 662-671.

36. Chen $B$, Wang $W$, Peng $X$, Jiang $H$, Zhang $S$, Li D, et al. The comprehensive mutational and phenotypic spectrum of TUBB8 in female infertility. Eur J Hum Genet. 2019; 27: 300-307.

37. Christou-Kent $M$, Kherraf ZE, Amiri-Yekta A, Le Blévec $E$, Karaouzène $T$, Conne B, et al. PATL2 is a key actor of oocyte maturation whose invalidation causes infertility in women and mice. EMBO Mol Med. 2018; 10.

38. Bojesen A, Juul S, Gravholt $\mathrm{CH}$. Prenatal and postnatal prevalence of Klinefelter syndrome: A national registry study. J Clin Endocrinol Metab. 2003; 88: 622-626.

39. Maiburg M, Repping S, Giltay J. The genetic origin of Klinefelter syndrome and its effect on spermatogenesis. Fertil Steril. 2012; 98: 253-260.

40. Daly RF, Harley JP. Frequency of XYY males in Wisconsin state correctional institutions. Clin Genet. 1980; 18: 116-122.

41. Clementini E, Palka C, lezzi I, Stuppia L, Guanciali-Franchi P, Tiboni GM. Prevalence of chromosomal abnormalities in 2078 infertile couples referred for assisted reproductive techniques. Hum Reprod. 2005; 20: 437-442. 


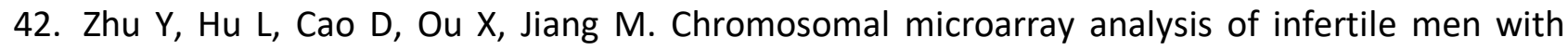
azoospermia factor microdeletions. Gene. 2020; 735: 144389.

43. Krausz C, Casamonti E. Spermatogenic failure and the Y chromosome. Hum Genet. 2017; 136: 637-655.

44. Krausz C, Hoefsloot L, Simoni M, Tüttelmann F. EAA/EMQN best practice guidelines for molecular diagnosis of Y-chromosomal microdeletions: State-of-the-art 2013. Andrology. 2014; 2: 5-19.

45. Lo Giacco D, Chianese C, Sánchez-Curbelo J, Bassas L, Ruiz P, Rajmil O, et al. Clinical relevance of Y-linked CNV screening in male infertility: New insights based on the 8-year experience of a diagnostic genetic laboratory. Eur J Hum Genet. 2014; 22: 754-761.

46. Shen Y, Xu J, Yang X, Liu Y, Ma Y, Yang D, et al. Evidence for the involvement of the proximal copy of the MAGEA9 gene in Xq28-linked CNV67 specific to spermatogenic failure. Biol Reprod. 2017; 96: 610-616.

47. Lo Giacco D, Chianese C, Ars E, Ruiz-Castañé E, Forti G, Krausz C. Recurrent X chromosome linked deletions: Discovery of new genetic factors in male infertility. J Med Genet. 2014; 51: 340-344.

48. Mueller JL, Skaletsky H, Brown LG, Zaghlul S, Rock S, Graves T, et al. Independent specialization of the human and mouse $X$ chromosomes for the male germ line. Nat Genet. 2013; 45: 1083-1087.

49. Cystic fibrosis mutation database. Toronto: Cystic fibrosis mutation database; 2011. Available from: www.genet.sickkids.on.ca/StatisticsPage.html

50. Chen H, Ruan YC, Xu WM, Chen J, Chan HC. Regulation of male fertility by CFTR and implications in male infertility. Hum Reprod Update. 2012; 18: 703-713.

51. Yu J, Chen Z, Ni Y, Li Z. CFTR mutations in men with congenital bilateral absence of the vas deferens (CBAVD): A systemic review and meta-analysis. Hum Reprod. 2012; 27: 25-35.

52. Bieth E, Hamdi SM, Mieusset R. Genetics of the congenital absence of the vas deferens. Hum Genet. 2020; 1-8.

53. Riera-Escamilla A, Enguita-Marruedo A, Moreno-Mendoza D, Chianese C, Sleddens-Linkels E, Contini $E$, et al. Sequencing of a 'mouse azoospermia' gene panel in azoospermic men: Identification of RNF212 and STAG3 mutations as novel genetic causes of meiotic arrest. Hum Reprod. 2019; 34: 978-988.

54. Dawes R, Lek M, Cooper ST. Gene discovery informatics toolkit defines candidate genes for unexplained infertility and prenatal or infantile mortality. NPJ Genom Med. 2019 15; 4: 1-11.

55. Sha Y, Zheng L, Ji Z, Mei L, Ding L, Lin S, et al. A novel TEX11 mutation induces azoospermia: A case report of infertile brothers and literature review. BMC Med Genet. 2018; 19: 63.

56. Yatsenko AN, Georgiadis AP, Röpke A, Berman AJ, Jaffe T, Olszewska M, et al. X-linked TEX11 mutations, meiotic arrest, and azoospermia in infertile men. N Engl J Med. 2015; 372: 20972107.

57. Oud MS, Volozonoka L, Smits RM, Vissers LELM, Ramos L, Veltman JA. A systematic review and standardized clinical validity assessment of male infertility genes. Hum Reprod. 2019; 34: 932-941.

58. Ray PF, Toure A, Metzler-Guillemain C, Mitchell MJ, Arnoult C, Coutton C. Genetic abnormalities leading to qualitative defects of sperm morphology or function. Clin Genet. 2017; 91: 217-232. 
59. Oud MS, Okutman Ö, Hendricks LAJ, de Vries PF, Houston BJ, Vissers LELM, et al. Exome sequencing reveals novel causes as well as new candidate genes for human globozoospermia. Hum Reprod. 2020; 35: 240-252.

60. Carmignac V, Dupont JM, Fierro RC, Barberet J, Bruno C, Lieury N, et al. Diagnostic genetic screening for assisted reproductive technologies patients with macrozoospermia. Andrology. 2017; 5: 370-380.

61. Touré A, Martinez G, Kherraf ZE, Cazin C, Beurois J, Arnoult C, et al. The genetic architecture of morphological abnormalities of the sperm tail. Hum Genet. 2020; 1-22.

62. Wu H, Whitcomb BW, Huffman A, Brandon N, Labrie S, Tougias E, et al. Associations of sperm mitochondrial DNA copy number and deletion rate with fertilization and embryo development in a clinical setting. Hum Reprod. 2019; 34: 163-170.

63. Skiba MA, Islam RM, Bell RJ, Davis SR. Understanding variation in prevalence estimates of polycystic ovary syndrome: A systematic review and meta-analysis. Hum Reprod Update. 2018; 24: 694-709.

64. Khan MJ, Ullah A, Basit S. Genetic Basis of polycystic ovary syndrome (PCOS): Current perspectives. Appl Clin Genet. 2019; 12: 249-260.

65. Zondervan KT, Becker CM, Koga K, Missmer SA, Taylor RN, Viganò P. Endometriosis. Nat Rev Dis Primers. 2018; 9.

66. Sapkota Y, Steinthorsdottir V, Morris AP, Fassbender A, Rahmioglu N, De Vivo I, et al. Metaanalysis identifies five novel loci associated with endometriosis highlighting key genes involved in hormone metabolism. Nat Commun. 2017; 8: 1-12.

67. Goulielmos GN, Matalliotakis M, Matalliotaki C, Eliopoulos E, Matalliotakis I, Zervou MI. Endometriosis research in the-omics era. Gene. 2020; 741: 144545.

68. Sang $Q$, Li B, Kuang Y, Wang X, Zhang Z, Chen B, et al. Homozygous mutations in WEE2 cause fertilization failure and female infertility. Am J Hum Genet. 2018; 102: 649-657.

69. Alazami AM, Awad SM, Coskun S, Al-Hassan S, Hijazi H, Abdulwahab FM, et al. TLE6 mutation causes the earliest known human embryonic lethality. Genome Biol. 2015; 16, 240.

70. Maddirevula S, Awartani K, Coskun S, AINaim LF, Ibrahim N, Abdulwahab F, et al. A genomics approach to females with infertility and recurrent pregnancy loss. Hum Genet. 2020; 1-9.

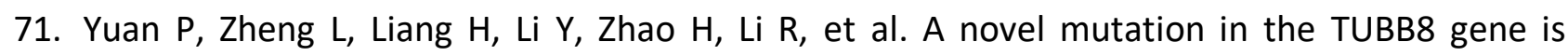
associated with complete cleavage failure in fertilized eggs. J Assist Reprod Genet. 2018; 35: 1349-1356.

72. Feng R, Sang Q, Kuang Y, Sun X, Yan Z, Zhang S, et al. Mutations in TUBB8 and human oocyte meiotic arrest. N Engl J Med. 2016; 374: 223-32.

73. Chen B, Li B, Li D, Yan Z, Mao X, Xu Y, et al. Novel mutations and structural deletions in TUBB8: Expanding mutational and phenotypic spectrum of patients with arrest in oocyte maturation, fertilization or early embryonic development. Hum Reprod. 2017; 32: 457-464.

74. Xu Y, Shi Y, Fu J, Yu M, Feng R, Sang $Q$, et al. Mutations in PADI6 cause female infertility characterized by early embryonic arrest. Am J Hum Genet. 2016; 99: 744-752.

75. Quintero-Ronderos P, Jiménez KM, Esteban-Pérez C, Ojeda DA, Bello S, Fonseca DJ, et al. FOXD1 mutations are related to repeated implantation failure, intra-uterine growth restriction and preeclampsia. Mol Med. 2019; 25: 37. 
76. The ESHRE Guideline Group on RPL, Bender Atik R, Christiansen OB, Elson J, Kolte AM, Lewis S, Middeldorp S, et al. ESHRE guideline: Recurrent pregnancy loss. Hum Reprod Open. 2018; 2018: hoy004.

77. Crosignani PG, Rubin BL. Recurrent spontaneous abortion. Hum Reprod. 1991; 6: 609-610.

78. Robbins SM, Thimm MA, Valle D, Jelin AC. Genetic diagnosis in first or second trimester pregnancy loss using exome sequencing: A systematic review of human essential genes. J Assist Reprod Genet. 2019; 36: 1539-1548.

79. Jauniaux E, Farquharson RG, Christiansen OB, Exalto N. Evidence-based guidelines for the investigation and medical treatment of recurrent miscarriage. Hum Reprod. 2006; 21: 22162222.

80. Grande M, Borrell A, Garcia-Posada R, Borobio V, Muñoz M, Creus M, et al. The effect of maternal age on chromosomal anomaly rate and spectrum in recurrent miscarriage. Hum Reprod. 2012; 27: 3109-3117.

81. Bernardi LA, Plunkett BA, Stephenson MD. Is chromosome testing of the second miscarriage cost saving? A decision analysis of selective versus universal recurrent pregnancy loss evaluation. Fertil Steril. 2012; 98: 156-161.

82. Foyouzi N, Cedars MI, Huddleston HG. Cost-effectiveness of cytogenetic evaluation of products of conception in the patient with a second pregnancy loss. Fertil Steril. 2012; 98: 151-155.

83. Hogge WA, Byrnes AL, Lanasa MC, Surti U. The clinical use of karyotyping spontaneous abortions. Am J Obstet Gynecol. 2003; 189: 397-400.

84. Van den Berg MM, van Maarle MC, van Wely M, Goddijn M. Genetics of early miscarriage. Biochim Biophys Acta. 2012; 1822: 1951-1959.

85. Robberecht C, Schuddinck V, Fryns JP, Vermeesch JR. Diagnosis of miscarriages by molecular karyotyping: Benefits and pitfalls. Genet Med. 2009; 11: 646-654.

86. Barber JC, Cockwell AE, Grant E, Williams S, Dunn R, Ogilvie CM. Is karyotyping couples experiencing recurrent miscarriage worth the cost? BJOG 2010; 117: 885-888.

87. Flynn H, Yan J, Saravelos SH, Li TC. Comparison of reproductive outcome, including the pattern of loss, between couples with chromosomal abnormalities and those with unexplained repeated miscarriages. J Obstet Gynaecol Res. 2014; 40: 109-116.

88. Franssen MT, Korevaar JC, Leschot NJ, Bossuyt PM, Knegt AC, Gerssen-Schoorl KB et al. Selective chromosome analysis in couples with two or more miscarriages: Case-control study. BMJ. 2005; 331: 137-141.

89. Franssen MT, Korevaar JC, van der Veen F, Leschot NJ, Bossuyt PM, Goddijn M. Reproductive outcome after chromosome analysis in couples with two or more miscarriages: Case-control study. BMJ. 2006; 332: 759-763.

90. Sugiura-Ogasawara M, Lin BL, Aoki K, Maruyama T, Nakatsuka M, Ozawa N, et al. Does surgery improve live birth rates in patients with recurrent miscarriage caused by uterine anomalies? J Obstet Gynaecol 2015; 35: 155-158.

91. Maddirevula S, Coskun S, Awartani K, Alsaif H, Abdulwahab FM, Alkuraya FS. The human knockout phenotype of PADI6 is female sterility caused by cleavage failure of their fertilized eggs. Clin Genet. 2017; 91: 344-345. 


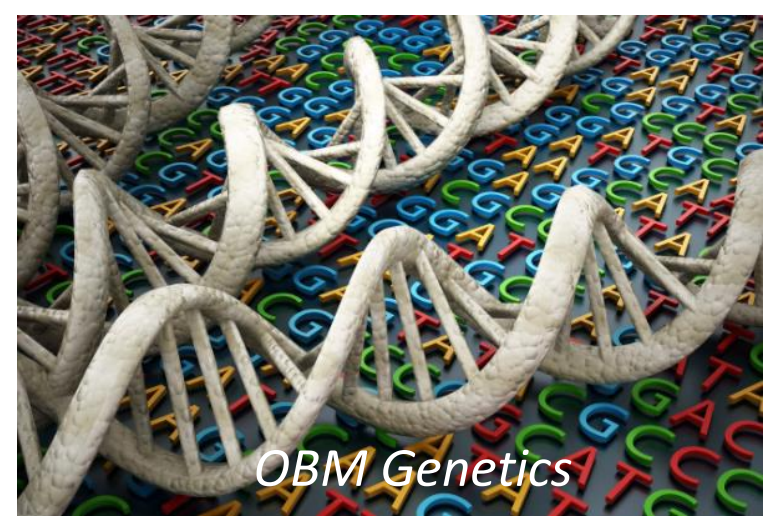

Enjoy OBM Genetics by:

1. Submitting a manuscript

2. Joining in volunteer reviewer bank

3. Joining Editorial Board

4. Guest editing a special issue

For more details, please visit:

http://www.lidsen.com/journals/genetics 